\title{
Recent Regionalism in UK and USA: A Legal and Economic Analysis
}

\author{
Badri G. Narayanan
}

Economist, School of Environment and Forestry Sciences, University of Washington Seattle, USA

\section{Isha Jaswal}

Associate Professor of Economics, School of Law, Delhi Metropolitan Education, India

\section{Lipika Sharma}

Associate Professor of Law, School of Law, Galgotia University, India

\begin{abstract}
While there have been a lot of analysis currently being conducted to analyze the recent trends across the world towards a new era of protectionism, many of them are either in the realm of law or economics; there is a dearth of studies analyzing them from a combined legal and economic perspective. Our paper is a unique attempt in this regard. We show from both legal and economic perspectives, that the new regionalist policy initiatives in UK and USA potentially have more negative effects than positive effects for the entire world in the future.
\end{abstract}

Keywords: international trade, law and economics, new regionalism.

JEL Classification: F14, F53, K22, L50.

(C) The Authors, 2017. This article is published with open access at ARMG Publishing.

\section{Introduction}

India's RBI Governor Urjit Patel remarked in the Third Kotak Family Distinguished Lecture that nations and world as whole has benefited from a liberal trading regime ${ }^{1}$. Stressing on the importance of global supply chain, he commented that the prices of shares of corporations have reached their high because of open trading system. He said with specific reference to Multi National Corporations (MNCs) of United States of America (USA) like IBM and Apple that these organizations have been able to convert themselves into such giant corporation because of the ease of sourcing the best manpower and products. Had USA government and other nations followed a protectionist policy regime, then these corporations would have had a different fate altogether ${ }^{2}$. Thus relatively liberal trading world helps foster growth of specific as well as global economy.

Nevertheless, the world is witnessing a paradigm shift towards nationalist sentiments weighing out global sentiments at large and regional outlook as well. Be it bringing back the manufacturing jobs or scrapping off the regional trade agreement as big as Trans Pacific Partnership (TPP); President Trump's presidential campaigning was all about fostering the nationalistic agenda. Moreover, his 2017 Trade Policy Agenda lays huge emphasis on fair trade in contrast to free trade. The undercurrent of this agenda which profess USA not to be bound by World Trade Organization (WTO) rules in case such rules acts against USA's interests seems to be a move furthering 'America First' propaganda of the President ${ }^{3}$.

The basis of this move comes from the unfair trade practices like dumping, undervalued foreign exchange, and violation of copyrights and patents etc. Moreover, regional trade agreements like North America Free Trade Agreement (NAFTA) have been held responsible for job losses in the USA's manufacturing sector ${ }^{4}$. The policy documents thus seem to lay stress on the giving preference to undertake bilateral rather than

\footnotetext{
${ }^{1}$ Where would Apple, IBM be if not for talent from across globe: Urjit Patel (2017, April 25). The Economic Times. Retrieved from http://economictimes.indiatimes.com/news/economy/policy/where-would-apple-ibm-be-if-not-for-talent-from-across-globe-urjitpatel/articleshow/58355329.cms?utm_source=ETnotifications\&utm_medium=editpush\&utm_campaign=Policy. 
multilateral trade agreements like the TPP. In lieu of this scenario, USA would not only renegotiate the terms of TPP but those of other agreements like NAFTA, and US-Korea FTA as well.

This might mean either USA exiting the World Trade Organization (WTO) or renegotiating trade ties, which would ultimately mean restricting imports to the USA. More so this might prompt other countries of the world to raise their trade barriers against USA and/or look out for other trading partners for regional alliances. For instance, Mexico has already started talks for trade ties with Argentina and Brazil ${ }^{5}$. International Monetary Fund's (IMF) report presupposes the benefits of trade ties among Latin American and Caribbean in response to USA's inward-looking regional policies ${ }^{6}$.

Another stark instance where nationalistic sentiments superseded regionalism is that of Brexit. According to critics, EU has not only stagnated economically but is rather an economic entity which is dysfunctional. Moreover, distrust in EU was majorly triggered on account of its inability to solve the economic problems after 2008, especially that of burgeoning unemployment in southern Europe. Specifically with regard to UK, in 2004 right to full freedom of movement was granted to nations which joined EU in 20047. Unlike the Western European countries except Sweden, UK did not exercise the Treaty right to restrict such movement for seven years ${ }^{8}$. The influx of workers heavily influenced the 'leave vote'. Beside, according to Dennison and Carl, Brexit was much likely because UK was the least integrated state in the $\mathrm{EU}^{9}$. Be it in terms of UK's FDI or imports to and from EU, emigrants in EU, trust in EU and strikingly the National relative to European identification; all factors contributed to the leave vote ${ }^{10}$.

Further, the China factor has also acted as a deterrent for European working class. After its accession to WTO in 2001, China was liable to its commitment to open-up its markets and commercial banking, and ensure fair trade practices etc. However, over the period of time, China has become more rigid as a market to access. Moreover its skewed state's supported policies have made China the largest producer of the world. USA has still been more active to counter its dumping activities; but EU's lacking defensive measures in trade has led to enormous manufacturing unemployment across Europe ${ }^{11}$.

Additionally and notably, Marine Le Pen's presidential campaign was based on rescuing the working class which has been abandoned by the elite French and Europeans in general ${ }^{12}$. In fact the two major parties of France had been defeated in the first round ever since 1958. Apparently, the political clout of France underwent a dramatic shift. Given that Mrs. Le Pen had garnered over 10.6 million votes at 33.9\%, more than half of the votes earned by the new president-elect Mr. Emmanuel Macron (66.1\% or 20.7 million votes) in the election results announced in May 2017, she is going to be a force to reckon with in France and in the EU in future, particularly in their upcoming parliamentary elections.

It is quite evident that the new genre of politicians is banking on the nationalist themes. President Trump and Brexit are vivid instances of such scenario which are building up especially around the developed world. In this context, the current studies such as Ciuriak et al (2014) focus on entirely economic model, or legal analysis; realistically, both perspectives need to be included in these analyses. Therefore, we attempt to bridge this gap in the literature by focusing on the following objectives:

1. To evaluate the impact of US trade restrictions imposed on Mexico and China on Gross Domestic Product (GDP), sectoral production and trade.

\footnotetext{
${ }^{5}$ Mano, R. (2017, May 12). Brazil, Mexico look to strengthen trade ties as NAFTA talks loom. REUTERS. Retrieved from http://www.reuters.com/article/us-brazil-mexico-grains/brazil-mexico-look-to-strengthen-trade-ties-as-nafta-talks-loomidUSKBN18804F.

${ }^{6}$ International Monetary Fund (March 2017). Cluster Report - Trade Integration in Latin America and the Caribbean. Retrieved from https://www.imf.org/en/Publications/CR/Issues/2017/03/10/Cluster-Report-Trade-Integration-in-Latin-America-and-theCaribbean-44735.

${ }^{7}$ Riley, A. (2016). Brexit: Causes and Consequences. Barcelona Centre for International Affairs (CIDOB). E-ISSN: 2013-4428. Retrieved from: https://www.cidob.org/publicaciones/serie de publicacion/notes internacionals/n1 159/brexit causes and consequences.

${ }^{8}$ Ibid.

9 Dennison, J. and Carl, N. (2016, July 18). The ultimate cause of Brexit: history, culture, and geography. Retrieved from: http://blogs.lse.ac.uk/politicsandpolicy/explaining-brexit/.

${ }^{10}$ Ibid.

11 Zalan, E. (2016, January 13). Divided EU debates China market economy status. euobserver. Retrieved from: https://euobserver.com/eu-china/131801.

${ }^{12}$ Willsher, K. (2015, March 22). Abandoned French working class ready to punish Left's neglect by voting for far right. the guardian. Retrieved from: https://www.theguardian.com/world/2015/mar/22/alienated-french-working-class-vote-far-right-claims-analyst.
} 
2. To assess the impact of UK trade restrictions imposed on EU27 on Gross Domestic Product (GDP), sectoral production and trade.

3. To examine the probable legal implications in international law on account of changing political clout in USA and European Union (EU).

\section{Economic research methodology}

In order to attain the first two objectives, the study makes use of Computable General Equilibrium Model. Before delving into methodology followed specific to this study, an attempt has been made to develop an understanding of this model and related concepts.

\section{Computable General Equilibrium (CGE) models}

An economy has prevalence of many agents like households, industrial sectors, and government etc. But resources available in an economy are limited and hence resource allocation includes trade-offs. Therefore, with simultaneous presence of agents in a huge number, it is cumbersome to optimize resource allocation in the midst of such trade-offs.

Moreover, while formulating a policy decision, it is important to analyse its possible impact on the stakeholders and economy as a whole. For example, theoretically, regional trade agreement may be believed to lead to efficient and better resource allocation. Still this policy cannot be recommended or implemented unless the impact of such agreement is indicated numerically. This is where the role of CGE models holds importance. These models are vital tools to quantitatively evaluate and investigate such policy issues. That is why they are known as computable general equilibrium models. Additionally, modification in trade policies has spillover effects. Due to this, decisions on making changes in these policies have been enormously dependent, since 1960, upon results obtained by CGE models. In effect, other approaches like economy-wide econometric modeling and input-output models have been essentially replaced by CGE models.

Another factor which further propagated the use of CGE modeling is its capability to handle detail. This has become possible due to advanced and improved data bases and computer software like GEMPACK, GAMS etc. Dixon, P.B. $(2008)^{13}$ notes that we could use CGE models for studying the results disaggregated along hundreds of industries, regions, occupations and family/household types.

\section{Global Trade Analysis Project (GTAP)}

GTAP, at Purdue University, USA, involves linkage of policy makers and scholars all around the globe who are working with the aim of bettering the quantitative examination of global economic policy matters within an economy-wide framework ${ }^{14}$. In effect, they are tirelessly engaged in conducting quantitative analysis of global policy issues.

GTAP has been used world-wide for economic analysis ever since its origin in the year 1993. For instance, the book of Martin and Winters (1995) ${ }^{15}$ consisted of five quantitative papers, of which three were based on GTAP data. The works of Anderson, et al. (1999) ${ }^{16}$, Hertel and Martin (1999) ${ }^{17}$, Francois (1999) ${ }^{18}$, Elbehri, et al. (1999) $)^{19}$, Hertel, et al. $(1999)^{20}$ which were included in conferences co-sponsored by the WTO and the World Bank during the Millennium Round of Multilateral Trade, Geneva were based on GTAP framework.

\footnotetext{
${ }^{13}$ Dixon, P. B. (2008). Trade policy in Australia and the development of computable general equilibrium modeling. Journal of Economic Integration, 605-630.

14 Purdue University. About GTAP: Global Trade Analysis Project. Retrieved from: https://www.gtap.agecon.purdue.edu/about/project.asp.

15 Martin, W., \& Winters, L. A. (1995). The Uruguay Round: Widening and Deepening the World Trading System. World Bank Publications.

${ }^{16}$ Anderson, K., Ingco, E., \& Ingco, M. (1999). Integrating agriculture into the WTO: the next phase. Trade and Development Centre.

${ }^{17}$ Hertel, T., \& Martin, W. (1999). Would developing countries gain from inclusion of manufactures in the WTO negotiations?

${ }^{18}$ Francois, J. (2000). The ghost of Rounds past: the Uruguay Round and the Shape of the next multilateral trade round. In Conference on Agriculture and the New Trade Agenda in the WTO, pp. 1-2.

${ }^{19}$ Elbehri, A., Ingco, M., Hertel, T., \& Pearson, K. (2000). Agriculture and WTO 2000: quantitative assessment of multilateral liberalization of agricultural policies. In Conference on Agriculture and the New Trade Agenda in the WTO, pp. 1-2.

${ }^{20}$ Hertel, T. W., Anderson, K., Francois, J. F., \& Martin, W. J. (2000). Agriculture and non-agricultural liberalization in the millennium round.
} 
Similarly, Chang $(2001)^{21}$, Verburg, et al. (2008) $)^{22}$, Badri and Walmsley (2008) ${ }^{23}$, Das, G. (2009) ${ }^{24}$, Ludena $(2010)^{25}$, Hertel et al. $(2015)^{26}$ are some of the renowned works based upon general equilibrium modeling.

\section{GTAP database}

One of the biggest achievements and, in effect, the contribution of Global Trade Analysis Project is the development of GTAP Database. This database attains uniqueness because it contains complete data on bilateral trade, transport and protection linkages of the world. Also, this database is completely documented. Moreover, this database represents the world economy and is used by numerous research agencies, international organizations, government bodies and other researchers around the globe as a vital input for analysis of global economic issues.

The current release of GTAP database is the GTAP 9 Data Base. This current and latest version includes 2004, 2007 and 2011 as reference years as well as 140 regions for all 57 GTAP commodities. This is documented in Aguiar et al $(2016)^{27}$ and Narayanan et al $(2015)^{28}$.

\section{GTAP model}

The standard GTAP Model, documented extensively by Hertel $(1997)^{29}$, is a multi-region, multi-sector, computable general equilibrium model, with perfect competition and constant returns to scale. Novel features of this model comprise a sophisticated demand function for the private household preferences, the explicit treatment of international trade and transport margins and a global mechanism which intermediates between global savings and consumption. Although GTAP model has standard neoclassical assumptions like full employment, they can be easily modified for analysis using alternative theories.

\section{GTAP software - RunGTAP}

The standard GTAP model is solved using GEMPACK which is a flexible system for solving CGE models. GEMPACK has been developed by the Centre of Policy Studies, Australia. RunGTAP can run the standard GTAP model with any GTAP Data Base. RunGTAP is anoptical interface to several GEMPACK programs. It facilitates the user using GTAP models, to run simulations in a Windows environment in an interactive manner.

Now the study reiterates to the objectives and elucidates the related methodology to be used for realisation of the objectives of the study.

This study makes use of GTAPv9 database which constitutes 140 regions and 57 sectors. GTAP Aggregator, developed by Professor Mark Horridge (Centre of Policy Studies), is used for regional, sectoral and factor aggregation. For analyses purpose these regions have been aggregated into six regions. These are USA, China, Mexico, UK, EU27 and Rest of the World (ROW). Further, the sectors have been clustered into Agriculture, Manufacturing and Services. In order to assess the likely impact of President Trump's drive towards inward-looking policy and Brexit, following experiments are undertaken separately:

Experiment I: Tariff barriers on agriculture and manufacturing sector are raised by $10 \%$ between USA and Mexico, and USA and China.

\footnotetext{
${ }^{21}$ Chang, H. C. (2001). A New Look at the Impact of Migration on the Wage Differential. Research Paper-University of Melbourne Department of Economics.

22 Verburg, P. H., Eickhout, B. \& van Meijl, H. (2008). A multi-scale, multi-model approach for analyzing the future dynamics of European land use. The Annals of Regional Science, 42(1), 57-77.

${ }^{23}$ Gopalakrishnan, B. N. \& Walmsley, T. L. (2008). Global trade, assistance, and production: The GTAP 7 data base. Global Trade Analysis Center, Department of Agricultural Economics, Purdue University.

${ }^{24}$ Das, G. G. (2009). A hybrid production structure in trade: theory and implications. International Review of Economics, 56(4), 359.

${ }^{25}$ Ludena, C. E. (2010). Agricultural productivity growth, efficiency change and technical progress in Latin America and the Caribbean.

${ }^{26}$ Taheripour, F., Hertel, T. W., Gopalakrishnan, B. N., Sahin, S., \& Escurra, J. J. (2015, July). Agricultural production, irrigation, climate change, and water scarcity in India. In 2015 AAEA \& WAEA joint annual meeting, pp. 26-28.

${ }^{27}$ Aguiar, Angel, Badri Narayanan \& Robert McDougall (2016). An Overview of the GTAP 9 Data Base. Journal of Global Economic Analysis, 1(1), 181-208.

${ }^{28}$ Narayanan, G., Badri, Angel Aguiar and Robert McDougall, Eds (2015). Global Trade, Assistance, and Production: The GTAP 9 Data Base, Center for Global Trade Analysis, Purdue University.

${ }_{29}$ T.W. Hertel (ed. 1997). Global Trade Analysis: Modeling and Applications, Cambridge University Press. Available at https://www.gtap.agecon.purdue.edu/products/gtap_book.asp.
} 
Experiment II: Tariff barriers on agriculture and manufacturing sector are raised by 10 percent between UK and EU27.

\section{Economic model findings}

USA's increased protection showed that the volume of merchandise exports and imports of USA will fall by 4.26\% and 5.09\% (Appendix A). The same were also observed to fall in case of Mexico by nearly 9\% and $16.7 \%$ and in case of China by $2.9 \%$ and $4.7 \%$ (Appendix A). In fact, total change in merchandise exports as well as imports turned out to be negative at the global level (Appendix A). Thus, world's merchandise trade may shrink if US raises its tariff against China and Mexico, and the latter respond in the same manner.

Moreover, the results also showed that production in agriculture and service sector of USA would decline whereas that in case of manufacturing would increase (Appendix A). For China and Mexico, output in agriculture and manufacturing sector were seen to rise and that in service sector declined (Appendix A). With further investigation, it was noteworthy that world GDP however would fall with GDP of USA, China and Mexico falling by $0.11 \%, 0.26 \%$ and $0.37 \%$ respectively (Appendix A).

In case of percentage change in GDP, the results were more striking in case of second experiment, wherein the UK raises tariffs with the EU and vice versa. With UK and EU27 imposing tariff barriers on each other, impact on GDP index of other regions included in the model appeared to be nil or negligible, except for China whose GDP index rose by $0.02 \%$ (Appendix B). However, UK would witness a fall in GDP by nearly $0.4 \%$ and EU27 by $0.03 \%$ (Appendix B). Consequently, the global GDP index will witness a decline in case of Brexit (Appendix B).

Further, the net volume of merchandise exports and imports at world level will reduce (Appendix B). In case of such exports, all regions are observed to witness a fall whereas in case of imports only UK and EU27 undergo a decline (Appendix B). Closer examination revealed that the overall merchandise trade contract majorly on account of UK's fall in merchandise exports and imports by approximately $6.6 \%$ and $10 \%$ respectively (Appendix B). As a result, UK's manufacturing output will fall by $2.9 \%$ (Appendix B).

\section{Legal analysis}

The history of civilization has been one of peoples coming together in larger and larger which includes collective proliferation of global bodies like the United Nations (UN), the World Trade Organization and the European Union (EU). An impeccable aspiration of creation of the EU brought the states of Europe together in a continent-wide commitment to cooperation and integration. But disillusionment with multilateralism is evident and the living examples are Brexit and President Trump's policies.

In the present scenario both the UK and USA governments are going to the pre-World War II path in terms of trade and commerce. Until 2016 the norm was multilateralism now they are shifting the policies of bilateralism. This is reflecting the mind set of individualistic growth i.e. going alone approach. Behind Trump's victory and Brexit referendum was the 'me' first factor. Both countries policy in this direction are doing to affect the international trade in a big way hence same cannot be ignored as a geography specific political change.

Hence there is major shift in policy with regard to competition law, trade related laws, immigration laws, export import policies and labour laws etc. This in turn will directly impact the laws of various other countries with which these nations will be doing business and same will have international impact. The direct tremors will be seen on immigration policies in a big way and the same has already started showing in USA.

Brexit's immediate implication will be the exit of UK from the market of EU and the preferential treatment given to UK in terms of tariffs, free movement, intellectual property rights all will be withdrawn once the procedure for withdrawal is formally over. This will affect the investment in the UK as well as the job market will also see lesser immigrant population from EU. On the other hand similar circumstance is building up in USA as President Trump has taken steps to boost America's economy and create jobs for Americans. Through executive orders his administration has started withdrawing from multilateral agreements and enters into bilateral agreements with countries of their choice and not under compulsion of multilateralism. Further he is also challenging the relevance of NATO in the recent scenario and laying emphasis on the moving out of the Climate Change talks by calling the whole concept of climate change a hoax. Hence there will be change in the policy related to fossil fuels. As after Brexit, UK is moving out of EU similarly USA 
has already moved out of North America Free Trade Agreement and Trans Pacific Partnership by executive order signed by President Trump which means both the countries are out on a route of bilateralism.

\section{Changes in UK}

Before understanding Brexit it's necessary to understand the functioning of EU. The EU can only legislate in certain areas and it has exclusive and shared competence. Under exclusive competence it can legislate on customs union, competition and some common policies. On the other hand under shared competence i.e. where EU has powers but has not come up with any laws then member countries are free to legislate on their own the areas are social policy, agriculture, consumer protection, transport and the environment.

After withdrawal from EU, UK may or may not join European Economic Area (EEA) but still will be subjected to EU laws. Now UK will take route of bilateralism. Conflict of situation is UK still will be subjected to European Competition Laws, as any undertakings whose conduct may have an effect on trade within the EU and will have to comply with its laws. This is clearly an extremely complex route.

The Competition law is the area where there are different opinions but agreement on one thing i.e. in every likelihood no major changes are expected in Competition Policy. UK adopted and implemented the key elements of the Treaty on the Functioning of the European Union (TFEU) relating to competition law through the Competition Act 1998 (CA98) ${ }^{30}$. If UK takes Switzerland route then it is possible that UK Competition and Markets Authority (CMA) may maintain links with other national authorities outside EU. Section 60 CA98 requires UK courts and the CMA to ensure that questions relating to UK competition law are interpreted in a way which is consistent with judgments of the Court of Justice of the EU. End of the day EU case law will not be binding for UK courts.

Currently both EU and UK competition law are based on two key prohibitions: a prohibition on anticompetitive agreements; and a prohibition on abuse of dominance. The prohibitions under EU law (Articles 101 and 102 of the Treaty on the Functioning of the European Union (TFEU)) and UK law (Sections 2 and 18 of the Competition Act 1998 (CA98)) are almost identical. The key difference is the geographical scope of the provisions. The CA98 prohibitions apply to agreements and conduct influencing trade within the UK, and the TFEU prohibitions apply where the effect on trade is between the Member States of the EU.

Agreements which infringe either EU competition law or UK competition law may benefit from an exemption, either individually or by a block exemption. EU individual and block exemptions currently apply "in parallel" under UK competition law. This means that agreements are exempt from the Section 2 CA98 prohibition, where they are covered by an EU block exemption, or would be covered if the agreement had an effect on trade between EU Member States. Examples of such block exemptions include the Vertical Agreements Block Exemption Regulation. Section 60 CA98 requires UK courts and the CMA to ensure that questions relating to UK competition law are interpreted in a way which is consistent with judgments of the Court of Justice of the EU. . End of the day EU case law will not be binding for UK courts.

Businesses may face double jeopardy in case of anti-competition investigation by UK and EU both. In particular, if the UK courts were no longer required to follow the decisions of the European Courts this may give rise, over time, to divergent interpretations which could gradually shift the direction of the two regimes. However, certain provisions of VRBER are solely designed to promote the Single Market, for example the prohibition on suppliers restricting the onward sales of products by their customers. Since the Competition and Market Authority (CMA) rarely investigates such restrictions where their effects are confined to the UK, this may be one area in which the UK position could deviate substantially from the EU's approach ${ }^{31}$. Merger control and anti-trust investigations

EU merger control operates on the basis of a 'one stop shop'. This means that a merger which has a "community dimension" will be assessed by the European Commission and CMA simultaneously it would also substantially increase the costs and administrative burden associated with such transactions. Full Brexit will diminish the UK's ability to influence EU mergers and investigations which might impact upon UK con-

\footnotetext{
30 Taylor Wessing (2016). The potential impact of Brexit on UK competition law. Retrieved from https://www.taylorwessing.com/download/article-brexit-competition-law.html.

31 Craig, R. (2016, May 3). The potential impact of Brexit on UK competition law. Taylor Wessing. Retrieved from https://www.lexology.com/library/detail.aspx?g=4d43fc9c-39f0-43e2-832f-2aa410e40bed.
} 
sumers $^{32}$. Whether there are any changes at all to UK competition laws will substantially depend upon the precise terms of the UK's exit.

Workers' rights are specifically referenced in the White Paper as an area where existing law will be preserved under the Great Repeal Act $^{33}$. Labour law provisions will be protected which are benefiting labour in any what way.

TUPE refers to the "Transfer of Undertakings (Protection of Employment) Regulations 2006" as amended by the "Collective Redundancies and Transfer of Undertakings (Protection of Employment) (Amendment) Regulations 2014" ${ }^{\prime 4}$. It has been confirmed that the vast CJEU case law relating to the Acquired Rights Directive (2001/23/EC) will continue to be binding after the UK leaves the EU.

UK will have to de-harmonize commercial rules as under EU due to single market economy tariff on goods, freedom to sell goods within EU without any kind of discrimination, similar export rules, similar minimum regulatory standards, product standard rules, commercial and consumer laws were established.

Businesses at present have single window to collect, pool and process the data from sales across EU for panEurope marketing strategy will have to be changed fundamentally.

Another important aspect of commerce and trade law is Intellectual Property Rights. They are territorial in nature hence due to Brexit all pan-EU intellectual property rights would seize to exist. As a natural consequence, the pan EU remedies for infringement will also be not available. Further it will have to be seen that whether both jurisdictions will still respect each other's court ordersor not.

\section{Changes in USA}

The commerce and trade is going to witness sea change in America as well. Countries which America choose not to do business with will have higher costs on imports; higher prices on exports; reduced access to American markets; reduced influence on other issues; may be likely to have overall negative impacts on the U.S. economy. "Trump on Trade" specifics are Scrapping of the Trans Pacific Partnership (TPP) vide Jan. $23^{\text {rd }}$ executive order, executive order to withdraw from North American Free Trade Agreement (NAFTA) in the month of May.

If multilateralism is dead, regional trade agreements are also not looking so good outside of Asia. With the rise of Trump and anti-EU sentiment, the Transatlantic Trade and Investment Partnership (TTIP) is lost at sea, and so is the EU-Canada Comprehensive Economic and Trade Agreement (CETA) ${ }^{35}$.

The world has been on a consistent trajectory since WW II to reduce tariffs, reduce Non- Tariff Barriers, open markets, standardize trade rules, and institutionalize mechanisms for dealing with trade matters etc. American strategy appears to be aimed at improving the U.S. position in international trade. This continues to show consensus in favor of unfettered international trade, and the idea of increasing benefits to American workers who lost their jobs due to impacts of international trade. Adding new or higher import duties on products such as air conditioners, cars, and cookies is to encourage producers to make them in the USA.

Other side of the coin is the reduced impact of America outside United Nations on global issues due to fading of multilateralism. As international treaties and agreement are package deals and affects area which are not part of treaty. This means America is most likely to flout various treaty norms and in turn will not take its international treaty obligations seriously and will not respect international law. USA stand to lose some specific protections and/or leverage applicable to all member states by scrapping above mentioned multilateral agreements.

32 Taylor Wessing (2016). The potential impact of Brexit on UK competition law. Retrieved from https://www.taylorwessing.com/download/article-brexit-competition-law.html.

${ }^{33}$ Lang, E., Hunter, I. and Froud, J. (2017, March31). Brexit: Employment and Immigration Law implications - the latest position. Bird \& Bird. Retrieved from https://www.twobirds.com/en/news/articles/2016/uk/brexit-employment-and-immigration-lawimplications.

${ }^{34}$ Transfer of Undertakings (TUPE). Retrieved from http://www.acas.org.uk/index.aspx?articleid=1655.

35 Brexit, Trump and the TPP mean Australia should pursue more bilateral trade agreements (January 17, 2017). The Conversation. Retrieved from https://theconversation.com/brexit-trump-and-the-tpp-mean-australia-should-pursue-more-bilateral-tradeagreements-71330. 
All these may lead to trade wars, particularly with the countries singled out by the President as "unfair". Some natural consequences will be trade war will increase prices on imports, while simultaneously cutting off access to export markets, not to mention many other negative impacts, such as: deteriorate political relations, negatively impact U.S. businesses with investments in the trade partner/opponent or block.

Another area of commerce and trade will be The Dodd-Frank Act, which is also been reviewed to bring tax reforms and have effective whistle blower provisions. By keeping the banking system under a closer watch, the Dodd-Frank Act seeks to eliminate the need for future taxpayer-funded bailouts ${ }^{36}$. Further EB-5 regulation which deals with immigration investor program will also be reconsidered to discourage immigration. Sensible tax reforms, such as an amnesty for multinational companies that repatriate foreign profits, will finally become law ${ }^{37}$. The Republicans' hegemony will enable easy agreement on tax cuts financed mainly by higher public borrowing, rather than by facing down special interest lobbies' resistance to the elimination of exemptions and loopholes. These tax reforms will create even bigger budget deficits, which in turn will stimulate more growth and inflation ${ }^{38}$.

Reforms are also targeted at banking sector. Another boost to economic growth will come from deregulation. While battles over energy and environmental laws may dominate the headlines, the biggest economic impact will come from reversing bank regulations ${ }^{39}$. As banks are encouraged to loosen lending standards, especially for middle-income households, an upswing in residential construction and debt-financed consumption should add further growth impetus ${ }^{40}$. Excessive deregulation could cause a re-run of the 2007 financial crisis, but that, too, is a risk for 2018 and beyond. It is tagged as Federal conservatism by his critics.

Trump administration is calling climate change and human impact on it is a hoax so there is a need to reopen coal, oil and gas generated energy. Another area of change is immigration under any head. To begin with HIB visa norms are already tightened through executive order, the category benedictory is also redefined. Further the companies are burdened to justify for hiring other than Americans with the detailed explanation clause.

In geopolitical terms, a tough USA trade stance provides China with the opportunity to increase its influence in the region, bolstering economic ties and making countries of the Pacific Rim less dependent on the American market. The Trump administration has also issued a warning to US companies against the misuse of H1-B Visas which results in discrimination against US workers. Another issue is a bill introduced in the house is The High-Skilled Integrity and Fairness Act of 2017 which will raise minimum the salary of an H1B worker to USD 130,000 from the USD 60,000 prescribed earlier. Trump drew a bright line on the H-1B visa: It "should include only the most skilled and highest-paid applicants and should never, ever be used to replace American workers ${ }^{41}$."

Mixed response to UK and USA policies will be reflected in Canberra as there are loud voices calling for "absolutely free" trade between Australia and the UK. According to some, a full-blown China- US trade war fought on currency manipulation is the single biggest economic threat to Australia.

A falling Chinese currency in combination with US protectionist measures would dampen the Chinese economy by way of reduced volumes of exports and higher interest rates spreading across the Asia Pacific and pushing down the price of commodities ${ }^{42}$. Protectionist western economy across the Atlantic will further swing the global pendulum of economic growth to Asia.

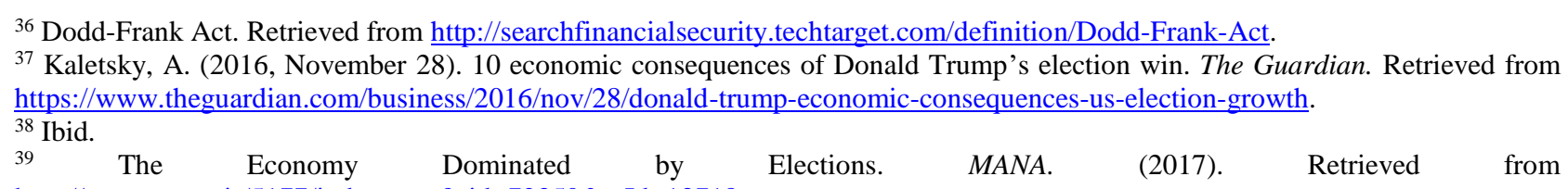
http://www.mana.ir/5177/index.aspx?nid=72350\&mId=13718.

${ }^{40}$ Kaletsky, A. (November, 2016). Ten Consequences of Trump. Conjuntura Global, REUNIÃO DE CONJUNTURA. 2016, December 5. Retrieved from https://www.pragmapatrimonio.com.br:3035/Interno/Arquivos/MidiaExterno/11884_Original.pdf.

${ }^{41}$ The case for importing skilled foreign workers: Trump's Kenosha doctrine is good for America. Editorial Board, Chicago Tribune. 2017, April 20. Retrieved from http://www.chicagotribune.com/news/opinion/editorials/ct-visa-worker-program-trump-edit0421-md-20170420-story.html

${ }^{42}$ Brexit, Trump and the TPP mean Australia should pursue more bilateral trade agreements. The Conversation. January 17, 2017. Retrieved from https://theconversation.com/brexit-trump-and-the-tpp-mean-australia-should-pursue-more-bilateral-tradeagreements-71330 
Thus, if the second half of the 20th century was the age of integration - of nations coming together and pooling sovereignty in pursuit of common goals - the 21 st century looks increasingly as an age of drifting apart. President Trump's trade policy is to concentrate on freer and fairer trade for Americans and Brexit to concentrate on individualistic national growth outside EU.

\section{Conclusions}

Our economic analysis shows a visible set of global repercussions of the regionalist policies by the USA and the UK. This may be reflected in lower GDP and lower output in different sectors. Our legal analysis suggests potential major changes coming up in the UK and the USA because of a broad regionalist approach, in areas as diverse as investment, labor rights, rules of trade and several economic aspects like growth and prices. Therefore, we conclude that the new regionalism has the potential to undo the gains from free trade generated over the past several decades. Nevertheless, there are a few positive aspects, particularly, for BREXIT, even in terms of freer trade. For example, the FTAs between EU and a Commonwealth country may be far more difficult than those between UK and Commonwealth countries.

\section{References}

1. Aguiar, Angel, Badri Narayanan, \& Robert McDougall (2016). An Overview of the GTAP 9 Data Base. Journal of Global Economic Analysis, 1(1), 181-208.

2. Anderson, K., Ingco, E., \& Ingco, M. (1999). Integrating agriculture into the WTO: the next phase. Trade and Development Centre.

3. Brexit, Trump and the TPP mean Australia should pursue more bilateral trade agreements (January 17, 2017). The Conversation.. Retrieved from https://theconversation.com/brexit-trump-and-the-tpp-meanaustralia-should-pursue-more-bilateral-trade-agreements-71330.

4. Chang, H. C. (2001). A New Look at the Impact of Migration on the Wage Differential. Research Paper-University of Melbourne Department of Economics.

5. Craig, R. (2016, May 3). The potential impact of Brexit on UK competition law. Taylor Wessing. Retrieved from https://www.lexology.com/library/detail.aspx?g=4d43fc9c-39f0-43e2-832f-2aa410e40bed.

6. Das, G. G. (2009). A hybrid production structure in trade: theory and implications. International Review of Economics, 56(4), 359.

7. Dennison, J. and Carl, N. (2016, July 18). The ultimate cause of Brexit: history, culture, and geography. Retrieved from: http://blogs.lse.ac.uk/politicsandpolicy/explaining-brexit/.

8. Dixon, P. B. (2008). Trade policy in Australia and the development of computable general equilibrium modeling. Journal of Economic Integration, 605-630.

9. Dodd-Frank Act. Retrieved from http://searchfinancialsecurity.techtarget.com/definition/Dodd-Frank-Act.

10. Elbehri, A., Ingco, M., Hertel, T., \& Pearson, K. (2000). Agriculture and WTO 2000: quantitative assessment of multilateral liberalization of agricultural policies. In Conference on Agriculture and the New Trade Agenda in the WTO, pp. 1-2.

11. Francois, J. (2000). The ghost of Rounds past: the Uruguay Round and the Shape of the next multilateral trade round. In Conference on Agriculture and the New Trade Agenda in the WTO, pp. 1-2.

12. Gopalakrishnan, B. N., \& Walmsley, T. L. (2008). Global trade, assistance, and production: The GTAP 7 data base. Global Trade Analysis Center, Department of Agricultural Economics, Purdue University.

13. Hertel, T. W. (ed. 1997). Global Trade Analysis: Modeling and Applications, Cambridge University Press. Available at https://www.gtap.agecon.purdue.edu/products/gtap_book.asp.

14. Hertel, T. W., Anderson, K., Francois, J. F., \& Martin, W. J. (2000). Agriculture and non-agricultural liberalization in the millennium round.

15. Hertel, T., \& Martin, W. (1999). Would developing countries gain from inclusion of manufactures in the WTO negotiations?

16. International Monetary Fund (March 2017). Cluster Report - Trade Integration in Latin America and the Caribbean. Retrieved from https://www.imf.org/en/Publications/CR/Issues/2017/03/10/ClusterReport-Trade-Integration-in-Latin-America-and-the-Caribbean-44735.

17. Kaletsky, A. (2016, November 28). 10 economic consequences of Donald Trump's election win. the guardian. Retrieved from https://www.theguardian.com/business/2016/nov/28/donald-trump-economicconsequences-us-election-growth. 
18. Kaletsky, A. (November, 2016). Ten Consequences of Trump. Conjuntura Global, REUNIÃO DE CONJUNTURA.

Retrieved

from https://www.pragmapatrimonio.com.br:3035/Interno/Arquivos/MidiaExterno/11884_Original.pdf.

19. Lang, E., Hunter, I. and Froud, J. (2017, March 31). Brexit: Employment and Immigration Law Implications - The Latest Position. Bird \& Bird. Retrieved from https://www.twobirds.com/en/news/articles/2016/uk/brexit-employment-and-immigration-lawimplications.

20. Ludena, C. E. (2010). Agricultural productivity growth, efficiency change and technical progress in Latin America and the Caribbean.

21. Mano, R. (2017, May 12). Brazil, Mexico look to strengthen trade ties as NAFTA talks loom. REUTERS. Retrieved from http://www.reuters.com/article/us-brazil-mexico-grains/brazil-mexico-look-tostrengthen-trade-ties-as-nafta-talks-loom-idUSKBN18804F.

22. Martin, W., \& Winters, L. A. (1995). The Uruguay Round: Widening and Deepening the World Trading System. World Bank Publications.

23. Narayanan, G., Badri, Angel Aguiar and Robert McDougall, Eds. (2015). Global Trade, Assistance, and Production: The GTAP 9 Data Base, Center for Global Trade Analysis, Purdue University.

24. Riley, A. (2016). Brexit: Causes and Consequences. Barcelona Centre for International Affairs (CIDOB). E-ISSN: 2013-4428. Retrieved from: https://www.cidob.org/publicaciones/serie_de_publicacion/notes_internacionals/n1_159/brexit_causes_ and consequences.

25. Taheripour, F., Hertel, T. W., Gopalakrishnan, B. N., Sahin, S., \& Escurra, J. J. (2015, July). Agricultural production, irrigation, climate change, and water scarcity in India. In 2015 AAEA \& WAEA joint annual meeting, pp. 26-28.

26. Taylor Wessing (2016). The potential impact of Brexit on UK competition law. Retrieved from https://www.taylorwessing.com/download/article-brexit-competition-law.html.

27. The case for importing skilled foreign workers: Trump's Kenosha doctrine is good for America. Editorial Board, Chicago Tribune. 2017, April 20. Retrieved from http://www.chicagotribune.com/news/opinion/editorials/ct-visa-worker-program-trump-edit-0421-md20170420-story.html.

28. The Economy Dominated by Elections. MANA. (2017). Retrieved from: http://www.mana.ir/5177/index.aspx?nid=72350\&mId=13718.

29. The fallout from Trump's new trade policy (2017, April 11), The Hindu Business Line. Retrieved from: http://www.thehindubusinessline.com/opinion/the-fallout-from-trumps-new-trade-policy/article 9631174.ece?homepage=true.

30. Transfer of Undertakings (TUPE). Retrieved from http://www.acas.org.uk/index.aspx ?articleid=1655

31. Verburg, P. H., Eickhout, B., \& van Meijl, H. (2008). A multi-scale, multi-model approach for analyzing the future dynamics of European land use. The annals of regional science, 42(1), 57-77.

32. Where would Apple, IBM be if not for talent from across globe: Urjit Patel (2017, April 25), The Economic Times. Retrieved from http://economictimes.indiatimes.com/news/economy/policy/where-wouldapple-ibm-be-if-not-for-talent-from-across-globe-urjit-patel/articleshow $/ 58355329 . \mathrm{cms}$ ?utm_source= ETnotifications\&utm_medium=editpush\&utm_campaign=Policy.

33. Willsher, K. (2015, March 22). Abandoned French working class ready to punish Left's neglect by voting for far right. The Guardian. Retrieved from https://www.theguardian.com/world/2015/mar/22/alienated-french-working-class-vote-far-right-claimsanalyst.

34. Zalan, E. (2016, January 13). Divided EU debates China market economy status. euobserver. Retrieved from: https://euobserver.com/eu-china/131801. 


\section{Appendix A}

Table 1. Results from Experiment I

\begin{tabular}{|c|c|c|}
\hline \multicolumn{2}{|c|}{ Change in GDP } \\
\hline qgdp & \% Change & Change (\$US million) \\
\hline USA & -0.11 & -17557 \\
\hline China & -0.26 & -19143 \\
\hline Mexico & -0.37 & -4370.25 \\
\hline UK & 0.02 & 404 \\
\hline EU27 & 0.01 & 1872 \\
\hline RestofWorld & 0.02 & 5908 \\
\hline
\end{tabular}

Authors' findings: GTAPv9.

\begin{tabular}{|c|c|c|}
\hline \multicolumn{3}{|c|}{ Change in imports } \\
\hline qiwreg & \% Change & Change (\$US million) \\
\hline USA & -5.09 & -136220 \\
\hline China & -4.72 & -78035 \\
\hline Mexico & -16.75 & -53960.1 \\
\hline UK & 0.4 & 3438.81 \\
\hline EU27 & 0.26 & 16519 \\
\hline RestofWorld & 0.77 & 64684 \\
\hline
\end{tabular}

Authors' findings: GTAPv9.

\begin{tabular}{|l|c|c|c|}
\hline qo & USA & China & Mexico \\
\hline Agriculture & -0.73 & 0.66 & 2.54 \\
\hline Manufacturing & 0.3 & 0.11 & 1.26 \\
\hline Other Services & -0.05 & -0.2 & -0.6 \\
\hline
\end{tabular}

Authors' findings: GTAPv9.

\section{Appendix B}

Table 2. Results from Experiment I

\begin{tabular}{|c|c|c|}
\hline \multicolumn{2}{|c|}{ Change in GDP } \\
\hline qgdp & \% Change & Change (\$US million) \\
\hline USA & 0 & 285 \\
\hline China & 0.02 & 1289.5 \\
\hline Mexico & 0 & -3.25 \\
\hline UK & -0.36 & -8951 \\
\hline EU27 & -0.03 & -5277 \\
\hline RestofWorld & 0.01 & 2738 \\
\hline
\end{tabular}

Authors' findings: GTAPv9.

\begin{tabular}{|c|c|c|}
\hline \multicolumn{3}{|c|}{ Change in exports } \\
\hline qiwreg & \% Change & Change (\$US million) \\
\hline USA & -0.2 & -3764 \\
\hline China & -0.05 & -1041.63 \\
\hline Mexico & -0.07 & -46881.4 \\
\hline UK & -6.62 & -25461.5 \\
\hline EU27 & -0.41 & -834 \\
\hline RestofWorld & -0.01 & \multicolumn{2}{c}{} \\
\hline
\end{tabular}

Authors' findings: GTAPv9. 


\begin{tabular}{|c|c|c|}
\hline & Change in imports & Change (\$US million) \\
\hline qiwreg & \% Change & 12290.25 \\
\hline USA & 0.46 & 5155.5 \\
\hline China & 0.31 & 410.09 \\
\hline Mexico & 0.13 & -87295.2 \\
\hline UK & -10.17 & -38026 \\
\hline EU27 & -0.61 & 29650 \\
\hline RestofWorld & 0.35 & \\
\hline
\end{tabular}

Authors' findings: GTAPv9.

\begin{tabular}{|c|c|c|c|c|c|c|}
\hline \multicolumn{7}{|c|}{ Percentage change in production } \\
\hline qo & USA & China & Mexico & UK & EU27 & Rest of World \\
\hline Agri & -0.02 & -0.02 & 0.03 & 0.92 & -0.14 & 0.01 \\
\hline Mnfc & 0.03 & -0.04 & -0.03 & -2.94 & 0.1 & 0.05 \\
\hline OthServices & -0.01 & 0.03 & 0.01 & 0.64 & -0.03 & -0.02 \\
\hline CGDS & 0.4 & 0.17 & 0.22 & -6.91 & -0.29 & 0.31 \\
\hline
\end{tabular}

Authors' findings' GTAPv9. 